\title{
Serum peptidome profiling for the diagnosis of colorectal cancer: discovery and validation in two independent cohorts
}

\author{
Hao Wang ${ }^{1, *}$, Chenghua Luo ${ }^{2, *}$, Shengtao Zhu ${ }^{3,4}$, Honghong Fang ${ }^{1}$, Qing Gao ${ }^{1}$, Siqi \\ $\mathbf{G e}^{1,5}$, Haixia $\mathbf{Q u}^{6}$, Qingwei Ma ${ }^{6}$, Hongwei Ren7, Youxin Wang ${ }^{1}$ and Wei Wang ${ }^{1,5}$ \\ ${ }^{1}$ Beijing Key Laboratory of Clinical Epidemiology, School of Public Health, Capital Medical University, Beijing 100069, China \\ ${ }^{2}$ Department of Retroperitoneal Tumors Surgery, Peking University International Hospital, Beijing 102206, China \\ ${ }^{3}$ Department of Gastroenterology, Beijing Friendship Hospital, Capital Medical University, Beijing 100069, China \\ ${ }^{4}$ National Center for Clinical Medical Research of Digestive Diseases, Beijing 100069, China \\ ${ }^{5}$ School of Medical and Health Sciences, Edith Cowan University, Perth 6027, Australia \\ ${ }^{6}$ Bioyong (Beijing) Technology Co., Ltd., Beijing 100085, China \\ ${ }^{7}$ School of Life Sciences, Peking University, Beijing 100871, China \\ *These authors have contributed equally to this work \\ Correspondence to: Wei Wang, email: wei.wang@ecu.edu.au \\ Youxin Wang, email: wangy@ccmu.edu.cn
}

Keywords: colorectal cancer, peptidome, MALDI-TOF MS, diagnosis panel

Received: May 18, $2017 \quad$ Accepted: June 29, $2017 \quad$ Published: July 26, 2017

Copyright: Wang et al. This is an open-access article distributed under the terms of the Creative Commons Attribution License 3.0 (CC BY 3.0), which permits unrestricted use, distribution, and reproduction in any medium, provided the original author and source are credited.

\section{ABSTRACT}

Colorectal cancer (CRC) is one of the most common malignant neoplasms worldwide. Except for the existing fecal occult blood test, colonoscopy and sigmoidoscopy, no widely accepted in vitro diagnostic methods have been available. To identify potential peptide biomarkers for CRC, serum samples from a discovery cohort (100 CRC patients and 100 healthy controls) and an independent validation cohort (91 CRC patients and 91 healthy controls) were collected. Peptides were fractionated by weak cation exchange magnetic beads (MB-WCX) and analysed by matrix-assisted laser desorption/ionization time-of-flight mass spectrometry (MALDITOF MS). Five peptides (peaks at $m / z$ 1895.3, 2020.9, 2080.7, 2656.8 and 3238.5) were identified as candidate biomarkers for CRC. A diagnostic panel based on the five peptides can discriminate CRC patients from healthy controls, with an accuracy of $\mathbf{9 1 . 8} \%$, sensitivity of $\mathbf{9 5 . 6 \%}$, and specificity of $\mathbf{8 7 . 9 \%}$ in the validation cohort. Peptide peaks at $m / z 1895.3,2020.9$ and 3238.5 were identified as the partial sequences of complement component 4 (C4), complement component 3 (C3) and fibrinogen a chain (FGA), respectively. This study potentiated peptidomic analysis as a promising in vitro diagnostic tool for diagnosis of CRC. The identified peptides suggest the involvement of the C3, C4 and FGA in CRC pathogenesis.

\section{INTRODUCTION}

Colorectal cancer (CRC) is the $3^{\text {rd }}$ most common cancer among men (after lung and prostate cancer) and the $2^{\text {nd }}$ most frequent cancer among women after breast cancer [1]. In 2012, 1.4 million new cases of CRC and nearly 0.7 million CRC-related deaths occurred worldwide [2]. The 5 -years relative survival rate for localized CRC is $90.3 \%$, and it decreases to $70.4 \%$ and $12.5 \%$ when the cancer has spread to the adjacent organs and distant organs, respectively [3]. Early diagnosis of CRC is an effective way to prolong the lives of CRC patients [3].

The American Cancer Society (ACS) recommends that individuals who are over 50 years old should schedule one of the following screenings: (1) a high-sensitivity fecal occult blood test (FOBT) every year, (2) a stool DNA test 
every 3 years, (3) a flexible sigmoidoscopy (FSIG) every 5 years, (4) a double-contrast barium enema every 5 years, (5) a computed tomography (CT) colonography every 5 years, or (6) a colonoscopy every 10 years [4]. However, due to the discomfort or high cost of these screening methods, only $55 \%$ of subjects aged 50 to 64 years have undergone a CRC screening test as suggested [5]. An examination of the entire colon by colonoscopy remains the golden standard for CRC screening, but people are hesitant to schedule a colonoscopy examination due to the complicated bowel preparation, associated discomfort, potential complications and high cost [6-9]. Although flexible sigmoidoscopy is less invasive than colonoscopy, this method is unable to examine the entire colon [10]. FOBT is non-invasive and economical, but it has relatively low sensitivity [11]. Carcinoembryonic antigen (CEA) has been extensively used as a blood-based marker for CRC prognosis [12], but it cannot be used as a diagnostic marker due to its relatively low specificity [13]. Currently, new blood-based tests that are accurate, safe, inexpensive, widely available, and associated with minimum patient discomfort are urgently required for the diagnosis of CRC.

The low-molecular-weight (LMW; $\leq 10 \mathrm{kDa}$ ) serum peptidome represents the array of endogenous peptides that present in both intracellular and extracellular space of the body [14]. It contains several physiologically important peptides, such as peptide hormones, peptide metabolic products and proteolytic fragments of larger precursor proteins [15]. The proteolytic degradative patterns in the serum peptidome, often refer to as peptidome signature or fingerprint, hold important information about many physiological and pathological processes, such as aging [16], type 2 diabetes [17] and Alzheimer's disease [18]. The progress of tumor's malignancy is accompanied by alterations in exoproteases activities, affecting the constitution of endogenous peptides that can indicate the presence/absence of cancer [19]. The profiling of the serum peptidome has been used for the diagnosis of CRC in several studies [20-30]. Fan et al (2006) recruited 72 CRC patients and 65 healthy controls and randomly divided them into two groups: a model construction group and a validation group [20]. They established a diagnostic model with two peptides that yielded a sensitivity of $94.74 \%$ and a specificity of $100 \%$ in the model construction phase and a sensitivity of $94.12 \%$ and a specificity of $100 \%$ in the validation phase [20]. Several peptidome diagnostic models for CRC were also created by Deng et al (2013) [21], Liu et al (2006) [24] and Pietrowska et al (2012) [25]. However, these studies were hampered with small sample sizes, lacked independent validation or peptide identification.

The cancer-related biomarkers occur in blood at very low concentration levels. Immunoglobulins, albumin and other 20 proteins that make up approximately $99 \%$ of the protein content of serum can mask other proteins or peptides [15]. Therefore, it is imperative to eliminate all these abundant proteins before peptides profiling. Weak cation exchange magnetic beads (MB-WCX) method is one of the established fractionation methods that have high capturing ability of low abundance proteins or peptides in serum samples [31]. Proteomic/peptidomic studies necessitate a sensitive and high-throughput technique. Both matrix-assisted laser desorption/ionization time-of-flight mass spectrometry (MALDI-TOF MS) and liquid chromatography-tandem mass spectrometry (LC-MS/MS) have been applied widely to the analysis of serum/plasma, saliva and urine samples to diagnose human diseases as well as for the identification of potential biomarkers of health status $[32,33]$.

This study aimed to determine serum peptides biomarkers for CRC by MALDI-TOF MS combined with MB-WCX. A peptide diagnostic panel based on a set of potential peptide biomarkers was generated from a discovery cohort, and then further tested in another independent validation cohort. The identification of these peptides was performed using LC-MS/MS.

\section{RESULTS}

\section{Characteristics of participants}

The demographic and clinical characteristics of the participants in the two independent cohorts are summarized in Table 1. No significant differences were found in the distributions of age and gender between the CRC patients and controls (all $P>0.05$ ). In the discovery cohort, $15.0 \%$ of the patients had early stage cancers (tumor-node-metastasis (TNM) stage I or II), where the remaining $85.0 \%$ had advanced stage cancers (TNM stage III or IV). In the validation cohort, $15.4 \%$ of the patients had early stage cancers (TNM stage I or II) and the remaining $84.6 \%$ had advanced stage cancers (TNM stage III or IV).

\section{Selection of candidate peptides}

The discovery cohort was used to select candidate peptides. The mass spectra of the serum samples from 100 CRC patients and 100 controls were obtained using MALDI-TOF MS (Figure 1). Among the 224 peptide peaks detected in the $\mathrm{m} / \mathrm{z}$ range from 1,000 to $10,000,22$ peaks were detected in at least $50 \%$ of the serum samples. Out of these 22 peptide peaks, 10 peaks $(\mathrm{m} / \mathrm{z} 1895.3,1944.0$, $2020.9,2080.7,2104.5,2656.8,3154.9,3238.5,3875.9$ and 4042.8) in the patients were significantly different from those in the controls and were selected as candidate peptides for further analysis $(P<0.05)$. Among these 10 candidate peptides, 3 peptides (peaks at $\mathrm{m} / \mathrm{z}$ 1895.3, 2020.9 and 3238.5) were at significantly higher levels, whereas the remaining 7 peptides (peaks at $\mathrm{m} / \mathrm{z}$ 1944.0, 2080.7, 2104.5, $2656.8,3154.9,3875.9$ and 4042.8) were at significantly lower levels in CRC patients compared with those of the controls (Figure 2). The area under the curve (AUC) was calculated to show the discriminatory power of these 10 
Table 1: Demographic and clinical characteristics of the participants

\begin{tabular}{lccccccc}
\hline Characteristics & \multicolumn{3}{c}{ Discovery cohort } & & \multicolumn{3}{c}{ Validation cohort } \\
\cline { 2 - 3 } & CRC patients & Controls & P-value & & CRC patients & Controls & $P$-value \\
\hline Participants numbers & 100 & 100 & - & 91 & 91 & - \\
Age (years) & $63.65 \pm 11.61$ & $61.36 \pm 8.30$ & 0.110 & & $63.03 \pm 12.72$ & $62.35 \pm 12.03$ & 0.771 \\
Gender (male/female) & $57 / 43$ & $57 / 43$ & 1.000 & & $50 / 41$ & $50 / 41$ & 1.000 \\
TNM stage & & & & & & - & - \\
I (\%) & $3(3.0 \%)$ & - & - & & $5(5.5 \%)$ & & - \\
II (\%) & $12(12.0 \%)$ & - & - & & $9(9.9 \%)$ & - & - \\
III (\%) & $58(58.0 \%)$ & - & - & & $29(31.9 \%)$ & - & - \\
IV (\%) & $27(27.0 \%)$ & - & - & & $48(52.7 \%)$ & - & - \\
\hline
\end{tabular}

Student $t$ test for age and chi-square test for gender. $P$-value lower than 0.05 was considered statistically significant.

candidate peptides, resulting a range from 0.623 to 0.980 of AUC in the discovery cohort (Table 2).

\section{Establishment of the peptide diagnostic panel}

To improve diagnostic accuracy for CRC, a multivariate binary logistic regression analysis was performed to establish a diagnostic panel with these 10 candidate peptides. The stepwise method (entry criteria:
$P<0.05$ and exclusion criteria: $P>0.10)$ was used to select the best panel of peptides. Consequently, 5 peptides (peaks at $m / z 1895.3,2020.9,2080.7,2656.8$, and 3238.5) were selected in the diagnostic panel (Table 3). Receiver operating characteristic (ROC) curve and the AUC were used to assess the diagnostic performance of the panel. The panel yielded an accuracy of $95.5 \%$, sensitivity of $96.0 \%$, specificity of $95.0 \%$, and AUC of 0.982 , indicating a high discriminatory power (Figure 3 and Table 4).

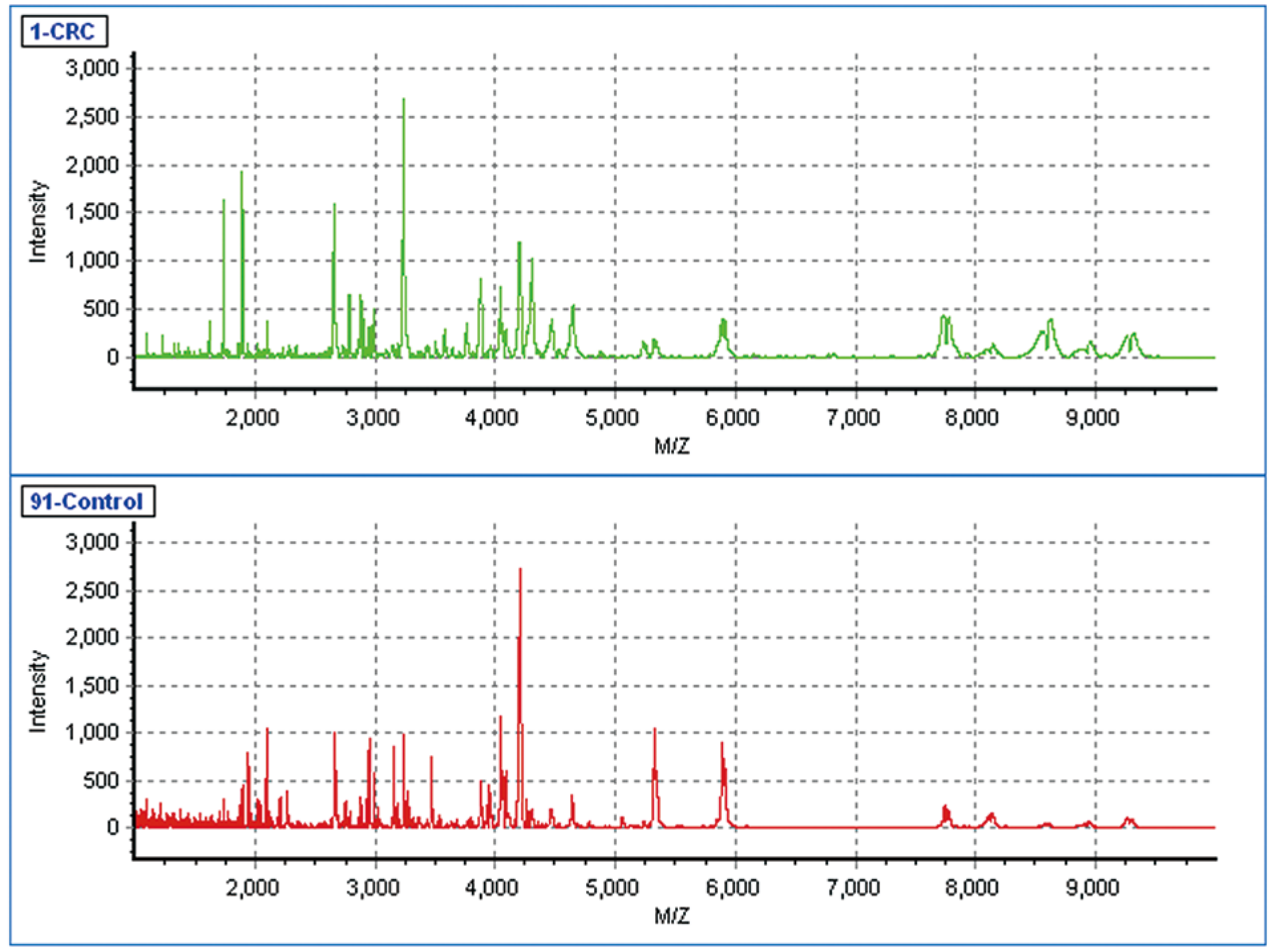

Figure 1: The MALDI-TOF spectra of the serum samples from a CRC patient and a healthy control. The green line indicated the mass spectra of a CRC patient and the red line indicated the mass spectra of a healthy individual. X-axis, mass-to-charge ratio $(\mathrm{m} / \mathrm{z})$; Y-axis, relative intensity. 
Table 2: Characteristics of candidate biomarkers in both discovery and validation cohorts

\begin{tabular}{|c|c|c|c|c|c|c|c|c|c|c|c|}
\hline \multirow[t]{2}{*}{$m / z$} & \multirow[t]{2}{*}{ Tendency $^{1}$} & \multicolumn{5}{|c|}{ Discovery cohort } & \multicolumn{5}{|c|}{ Validation cohort } \\
\hline & & Ave $(C)^{2}$ & $\operatorname{Ave}(\mathbf{N})^{3}$ & $P$-value ${ }^{4}$ & $\mathbf{A} \mathbf{U} \mathbf{C}^{5}$ & $95 \% \mathrm{CI}^{6}$ & $\operatorname{Ave}(C)^{2}$ & $\operatorname{Ave}(\mathbf{N})^{3}$ & $P$-value ${ }^{4}$ & $\mathbf{A} \mathbf{U C}^{5}$ & $95 \% \mathrm{CI}^{6}$ \\
\hline 1895.3 & $\uparrow$ & 2664.8 & 374.7 & $<0.001$ & 0.838 & $(0.780-0.895)$ & 2949.0 & 499.7 & $<0.001$ & 0.845 & $(0.783-0.906)$ \\
\hline 1944.0 & $\downarrow$ & 858.5 & 3103.8 & $<0.001$ & 0.906 & $(0.863-0.949)$ & 918.3 & 2741.0 & $<0.001$ & 0.841 & $(0.782-0.901)$ \\
\hline 2020.9 & $\uparrow$ & 3328.8 & 320.5 & $<0.001$ & 0.746 & $(0.671-0.822)$ & 4562.3 & 911.0 & $<0.001$ & 0.823 & $(0.754-0.892)$ \\
\hline 2080.7 & $\downarrow$ & 295.8 & 1187.9 & $<0.001$ & 0.896 & $(0.849-0.942)$ & 221.2 & 1016.4 & $<0.001$ & 0.893 & $(0.844-0.943)$ \\
\hline 2104.5 & $\downarrow$ & 132.8 & 544.7 & $<0.001$ & 0.906 & $(0.864-0.948)$ & 90.0 & 511.1 & $<0.001$ & 0.934 & $(0.896-0.971)$ \\
\hline 2656.8 & $\downarrow$ & 565.6 & 704.3 & $<0.001$ & 0.673 & $(0.597-0.750)$ & 471.7 & 696.4 & $<0.001$ & 0.699 & $(0.621-0.777)$ \\
\hline 3154.9 & $\downarrow$ & 145.8 & 1566.3 & $<0.001$ & 0.980 & $(0.963-0.996)$ & 132.6 & 1330.0 & $<0.001$ & 0.918 & $(0.872-0.963)$ \\
\hline 3238.5 & $\uparrow$ & 1015.9 & 451.2 & $<0.001$ & 0.623 & $(0.545-0.701)$ & 680.4 & 456.9 & 0.456 & 0.535 & $(0.450-0.619)$ \\
\hline 3875.9 & $\downarrow$ & 349.7 & 557.3 & $<0.001$ & 0.733 & $(0.660-0.806)$ & 248.3 & 509.1 & $<0.001$ & 0.759 & $(0.685-0.834)$ \\
\hline 4042.8 & $\downarrow$ & 271.5 & 940.5 & $<0.001$ & 0.859 & $(0.802-0.916)$ & 112.1 & 824.1 & $<0.001$ & 0.897 & $(0.849-0.945)$ \\
\hline
\end{tabular}

${ }^{1}$ Tendency $\uparrow$ represent the peaks intensity of CRC patients was higher than the controls, $\downarrow$ represent the peaks intensity of the CRC patients was lower than the controls; ${ }^{2}$ Average intensity of peaks for the CRC patients; ${ }^{3}$ Average intensity of peaks for the controls; ${ }^{4} \mathrm{P}$-value calculated with the Wilcoxon test; ${ }^{5}$ Area under ROC curve; ${ }^{6} 95 \%$ confidence intervals; $P$-value lower than 0.05 was considered statistically significant.

\section{External validation of the peptide diagnostic panel}

The same parameters generated from the discovery cohort were then used in the validation cohort to validate the diagnostic performance of the peptide diagnostic panel. The diagnostic panel yielded an accuracy of $91.8 \%$, sensitivity of $95.6 \%$, specificity of $87.9 \%$, and AUC of 0.932 in the validation cohort, with similar results found in the discovery cohort (Figure 3 and Table 4).

\section{Peptide identification}

By LC-MS/MS detection, the amino acid sequences of 3 peptides (peaks at $\mathrm{m} / \mathrm{z} 1895.3,2020.9,3238.5$ ) were identified as the partial sequences of complement component 4 (C4), complement component 3 (C3) and fibrinogen $\alpha$ chain (FGA), respectively (Table 5). However, we failed to identify the amino acid sequences of peptide peaks at $\mathrm{m} / \mathrm{z} 2080.7$ and 2656.8. The unknown modification on peptides may contribute to this phenomenon [34].

\section{DISCUSSION}

Various studies have suggested that serum peptidome is a promising tool for the effective identification of CRC patients [20-30]. Although the discriminatory peptides were not consistent among those studies because of the diverse methodology of sample preparation, measurement
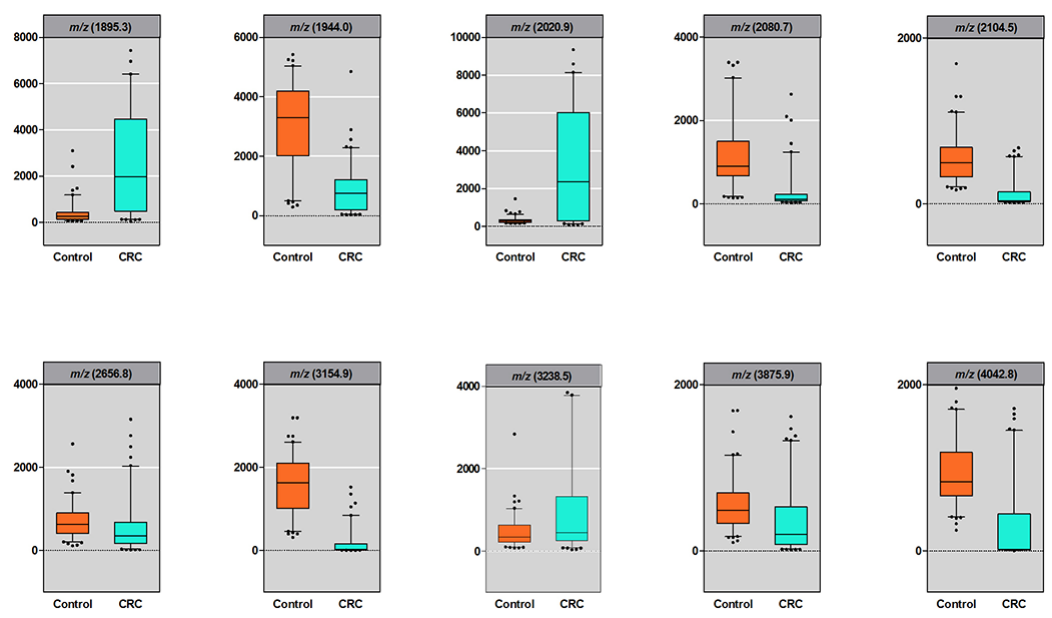

Figure 2: Box plots of peaks intensity in discovery cohort. Results are presented as box and whisker plots: median, middle lines; 25-75th percentiles, rectangles; range, lines; outliers, markers. 
Table 3: Diagnostic panel in the discovery cohort

\begin{tabular}{lcccc}
\hline $\boldsymbol{m} / \boldsymbol{z}$ & $\boldsymbol{\beta}$ & OR & $\mathbf{9 5 \%} \mathbf{C I}$ & $\boldsymbol{P}$-value \\
\hline 1895.3 & 0.104 & 1.110 & $(1.007-1.223)$ & 0.036 \\
2020.9 & 0.180 & 1.197 & $(1.045-1.371)$ & 0.010 \\
2080.7 & -0.118 & 0.888 & $(0.797-0.990)$ & 0.032 \\
2656.8 & -0.525 & 0.592 & $(0.467-0.750)$ & $<0.001$ \\
3238.5 & 0.481 & 1.617 & $(1.330-1.966)$ & $<0.001$ \\
Constant & -1.237 & 0.290 & & 0.088 \\
\hline
\end{tabular}

$P$-value lower than 0.05 was considered statistically significant. $\beta$, regression coefficient; OR, odds ratio; $\mathrm{CI}$, confidence interval.

and/or data processing, there were some common features of those studies [35]. For example, all the diagnostic models yielded high accuracies. Moreover, fragment of $\mathrm{C} 3$ was reported as a candidate biomarker in three reports $[25,27,30]$. In our study, we utilized MB-WCX coupled with MALDI-TOF MS to analyse 382 serum samples. We established a promising diagnostic panel to diagnose CRC with 5 serum peptides (peaks at $\mathrm{m} / \mathrm{z} 1895.3,2020.9$, 2080.7, 2656.8 and 3238.5). The diagnostic panel was able to discriminate CRC patients from healthy controls with high accuracy (discovery cohort: accuracy $95.5 \%$, sensitivity $96.0 \%$, specificity $95.0 \%$ and AUC 0.982 ; independent validation cohort: accuracy $91.8 \%$, sensitivity $95.6 \%$, specificity $87.9 \%$ and AUC 0.932 ). In addition, three diagnostic peptides were identified as fragments of $\mathrm{C} 4, \mathrm{C} 3$ and FGA, respectively. The identification and functional analysis of the discriminating peptides might provide new insights into cancer behaviours.

External validation is a critical step in introducing a new diagnostic model, as it evaluates the performance and transportability of a model using data that were not included in the model construction. Most of diagnostic models of CRC either had no validations [26], or had only internal validations, while only three studies were externally validated $[23,24,30]$ (Table 6 ). In this study, we developed and validated the diagnostic panel with high sensitivity and specificity in both discovery and validation cohorts with relative large samples, suggesting that the established diagnostic panel may have a potential of high performance in generalization.

Several potential peptide biomarkers, arising from apolipoprotein A-1, apolipoprotein C-1, C3, C4 and serine/threonine kinase 4 (STK4) have been identified by previous studies [23, 25-27]. Consistent with the reports of Pietrowska et al (2011) [25] and Ward et al (2006) [27], we also identified $\mathrm{C} 3$ peptides and $\mathrm{C} 4$ peptides as candidate biomarkers for CRC. $\mathrm{C} 3$ and $\mathrm{C} 4$ play critical roles in the activation of the complement system [36]. The excessive complement activation and complement deficiencies may contribute to several diseases and pathological conditions [37]. Increased complement activity was observed in cancer [38], while decreased complement activity has
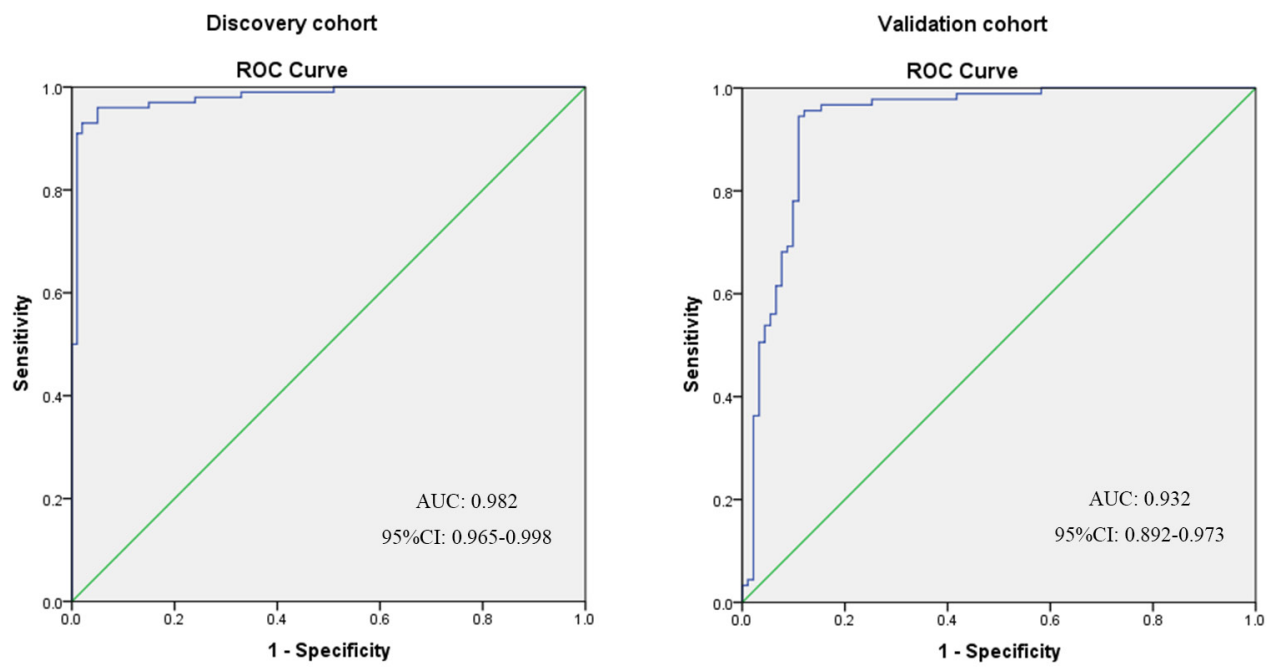

Figure 3: ROC curves of peptide diagnostic panel in the discovery and validation cohorts. ROC curves illustrating the performance of peptide diagnostic panel in discriminating CRC patients from healthy controls. 
Table 4: Diagnostic performance of the diagnostic panel in the discovery and validation cohorts

\begin{tabular}{|c|c|c|c|c|c|c|c|c|}
\hline & \multirow{2}{*}{$\begin{array}{c}\text { Diagnostic } \\
\text { group }\end{array}$} & \multicolumn{2}{|c|}{ Real group } & \multirow{2}{*}{$\begin{array}{c}\text { Accuracy } \\
\text { rate }\end{array}$} & \multirow{2}{*}{$\begin{array}{c}\text { Sensitivity } \\
(95 \% \text { CI) }\end{array}$} & \multirow{2}{*}{$\begin{array}{c}\text { Specificity } \\
\text { (95\% CI) }\end{array}$} & \multirow{2}{*}{$\begin{array}{c}\text { AUC } \\
(95 \% \mathrm{CI})\end{array}$} & \multirow[t]{2}{*}{$P$-value } \\
\hline & & $\begin{array}{c}\text { CRC } \\
\text { patients }\end{array}$ & Controls & & & & & \\
\hline $\begin{array}{l}\text { Discovery } \\
\text { cohort }\end{array}$ & $\begin{array}{c}\text { CRC } \\
\text { patients }\end{array}$ & 96 & 5 & $95.5 \%$ & $96.0 \%$ & $95.0 \%$ & 0.982 & $<0.001$ \\
\hline$(n=200)$ & Controls & 4 & 95 & & $(92.2 \%-99.8 \%)$ & $(90.7 \%-99.3 \%)$ & $(0.965-0.998)$ & \\
\hline $\begin{array}{l}\text { Validation } \\
\text { cohort }\end{array}$ & $\begin{array}{c}\text { CRC } \\
\text { patients }\end{array}$ & 87 & 11 & $91.8 \%$ & $95.6 \%$ & $87.9 \%$ & 0.932 & $<0.001$ \\
\hline$(n=182)$ & Controls & 4 & 80 & & $(91.6 \%-99.6 \%)$ & $(81.5 \%-94.3 \%)$ & $(0.892-0.973)$ & \\
\hline
\end{tabular}

Table 5: Identified candidate peptide biomarkers for CRC

\begin{tabular}{lcc}
\hline $\boldsymbol{m} / \boldsymbol{z}$ & Sequence & Protein name \\
\hline 1895.3 & R.NGFKSHALQLNNRQIR.G & Complement component 4 (C4) \\
2020.9 & R.SSKITHRIHWESASLLR.S & Complement component 3 (C3) \\
2080.7 & N/A & N/A \\
2656.8 & N/A & N/A \\
3238.5 & K.SYKMADEAGSEADHEGTHSTKRGHAK & Fibrinogen $\alpha$ chain (FGA) \\
\hline
\end{tabular}

been observed in bacterial infections [39, 40]. Patients with active lupus erythematosus may have lower levels of C3 and C4 than healthy controls [41]. The complement system is a central part of immune system regarded as the first defence against "non-self" cells [42]. It contributes to immune cell activation, pathogen elimination and immune surveillance against cancer [43]. Neoplastic transformation of tumour cells can generate tumour-associated antigens that distinguish malignant cells form normal ones. The components of the complement play a role in anti-tumour immune response through complement-dependent cellular cytotoxicity (CDCC) [44]. Various studies demonstrated that certain tumour cells activate complements. Elevated levels of $\mathrm{C} 3$ are present in patients with ovarian cancer [45]. The lectin pathway of complement activation has been found to be significantly increased in patients with CRC [46]. High expression of complement regulatory proteins were associated with poor prognosis of CRC [47]. Our results indicated the possibility of use of complementrelated proteins/peptides as new cancer biomarkers. A more systematic analysis of abnormalities in the levels of complement-related proteins/peptides occurring in serum of cancer patients is needed, which can also contribute to better understanding of the dynamic interplay between CRC and complements.

The peak at $\mathrm{m} / \mathrm{z} 3238.5$ identified as a fragment of FGA, showed a higher intensity in the CRC patients compared to the healthy controls. This peptide may reflect the status of high fibrinogen level in CRC patients. Fibrinogen is a serum protein secreted by hepatocytes and plays a central role in coagulation [48]. Elevated fibrinogen level is associated with malignant growth and hematogenous metastasis $[49,50]$. The fibrinogen receptors of malignant cells can bind the fibrinogen. The excessive fibrinogen may act as a physical barrier that can protect the malignant cells from the NK-mediated killing. Thus, high fibrinogen level enhances the early survival of tumour cells by protecting malignant cells from eliminating by the innate immune system [51]. Several studies have reported that increase of plasma fibrinogen level in patients with various types of malignancy, including colorectal cancer [52-54], lung cancer [55], pancreas cancer [56], ovarian cancer [57] and gastric cancer [58].

It is suggested that higher or lower intensities of various peptides in cancer serum can be originated not only from up- or down-regulation of the parent proteins, but from cancer-specific exoprotease activities as well. It has been proved that profiling of exoproteases is altered in several cancers, e.g., ectopeptidasea CD10, CD13, CD26 and CD143 are up-regulated in gastric cancer [59] and methionine aminopeptidase 2 are up-regulated in colorectal cancer [60]. Our work was based on the hypothesis that the different peptide patterns observed in controls and cancer patients were caused by the cancer-specific exoprotease activities. 
Table 6: The comparison of the present study with similar studies

\begin{tabular}{|c|c|c|c|c|c|c|c|c|}
\hline Studies & $\begin{array}{c}\text { MS } \\
\text { methods }\end{array}$ & Population & $\begin{array}{c}\text { Discovery } \\
\text { cohort } \\
\text { (CRC/ } \\
\text { control) }\end{array}$ & $\begin{array}{c}\text { Validation } \\
\text { cohort } \\
\text { (CRC/ } \\
\text { control) }\end{array}$ & $\begin{array}{c}\text { Validation } \\
\text { methods }\end{array}$ & Sensitivity & Specificity & Identification \\
\hline $\begin{array}{l}\text { The present } \\
\text { study }\end{array}$ & $\begin{array}{l}\text { MALDI- } \\
\text { TOF }\end{array}$ & Asians & $100 / 100$ & $91 / 91$ & $\begin{array}{c}\text { External } \\
\text { validation }\end{array}$ & $95.6 \%$ & $87.9 \%$ & $\mathrm{C} 4, \mathrm{C} 3, \mathrm{FGA}$ \\
\hline $\begin{array}{l}\text { Fan et al } 2012 \\
{[20]}\end{array}$ & $\begin{array}{l}\text { MALDI- } \\
\text { TOF }\end{array}$ & Asians & $38 / 32$ & $34 / 33$ & $\begin{array}{c}\text { Split } \\
\text { samples }\end{array}$ & $94.1 \%$ & $100 \%$ & ---- \\
\hline $\begin{array}{l}\text { Deng et al } \\
2014^{[21]}\end{array}$ & $\begin{array}{l}\text { MALDI- } \\
\text { TOF }\end{array}$ & Asians & $33 / 32$ & $34 / 33$ & $\begin{array}{c}\text { Split } \\
\text { samples }\end{array}$ & $100 \%$ & $100 \%$ & ---- \\
\hline $\begin{array}{l}\text { De Noo et al } \\
2006^{[22]}\end{array}$ & $\begin{array}{l}\text { MALDI- } \\
\text { TOF }\end{array}$ & Caucasians & $66 / 50$ & ---- & $\begin{array}{c}\text { Cross- } \\
\text { validation }\end{array}$ & $95.2 \%$ & $90.0 \%$ & ---- \\
\hline $\begin{array}{l}\text { Engwegen } \\
\text { et al } 2006^{[23]}\end{array}$ & $\begin{array}{l}\text { SELDI- } \\
\text { TOF }\end{array}$ & Caucasians & $40 / 49$ & $37 / 31$ & $\begin{array}{c}\text { External } \\
\text { validation }\end{array}$ & $89.5 \%$ & $88.9 \%$ & Apolipoprotein $\mathrm{C} 1, \mathrm{~A} 1$ \\
\hline $\begin{array}{l}\text { Liu et al } 2009 \\
\text { [24] }\end{array}$ & $\begin{array}{l}\text { SELDI- } \\
\text { TOF }\end{array}$ & Asians & $74 / 48$ & $60 / 39$ & $\begin{array}{c}\text { External } \\
\text { validation }\end{array}$ & $95.0 \%$ & $94.78 \%$ & ---- \\
\hline $\begin{array}{l}\text { Pietrowska } \\
\text { et al 2011 }\end{array}$ & $\begin{array}{l}\text { MALDI- } \\
\text { TOF }\end{array}$ & Caucasians & $35 / 45$ & ---- & $\begin{array}{c}\text { Cross- } \\
\text { validation }\end{array}$ & $68.6 \%$ & $81.9 \%$ & $\mathrm{C} 4 \mathrm{~A}, \mathrm{C} 3$ \\
\hline $\begin{array}{l}\text { Zhai et al } 2012 \\
\text { [26] }\end{array}$ & $\begin{array}{l}\text { SELDI- } \\
\text { TOF }\end{array}$ & Asians & $73 / 26$ & ---- & $\begin{array}{c}\text { No } \\
\text { validation }\end{array}$ & ---- & ---- & STK4 \\
\hline $\begin{array}{l}\text { Ward et al } \\
2006^{[27]}\end{array}$ & $\begin{array}{l}\text { SELDI- } \\
\text { TOF }\end{array}$ & Caucasians & $62 / 31$ & ---- & $\begin{array}{c}\text { Cross- } \\
\text { validation }\end{array}$ & $94.0 \%$ & $96.0 \%$ & $\begin{array}{l}\text { C3a, Apolipoprotein } \\
\text { C1 }\end{array}$ \\
\hline $\begin{array}{l}\text { Yu et al } \\
2004^{[28]}\end{array}$ & $\begin{array}{l}\text { SELDI- } \\
\text { TOF }\end{array}$ & Asians & $55 / 92$ & ---- & $\begin{array}{c}\text { Cross- } \\
\text { validation }\end{array}$ & $89.0 \%$ & $92.0 \%$ & ---- \\
\hline $\begin{array}{l}\text { Chen et al } \\
2004^{[29]}\end{array}$ & $\begin{array}{l}\text { SELDI- } \\
\text { TOF }\end{array}$ & Asians & $55 / 92$ & ---- & $\begin{array}{c}\text { Cross- } \\
\text { validation }\end{array}$ & $91.0 \%$ & $93.0 \%$ & ---- \\
\hline $\begin{array}{l}\text { Habermann } \\
\text { et al } 2006^{[30]}\end{array}$ & $\begin{array}{l}\text { SELDI- } \\
\text { TOF }\end{array}$ & Caucasians & $58 / 32$ & $38 / 21$ & $\begin{array}{c}\text { External } \\
\text { validation }\end{array}$ & $96.8 \%$ & $96.2 \%$ & $\mathrm{C} 3 \mathrm{a}$ \\
\hline
\end{tabular}

SLEDI-TOF MS, surface-enhanced laser desorption/ionization time-of-flight mass spectrometry; MALDI-TOF MS, matrixassisted laser desorption/ionization time-of flight mass spectrometry; STK4, serine/threonine kinase 4; C3, complement component 3; C4, complement component 4; FGA, Fibrinogen $\alpha$ chain.

Although C3, C4 and FGA are not CRC-specific biomarkers, the profiling of CRC-specific peptide pattern and/or CRCspecific peptide sequence has potential value in diagnosis of CRC. Additionally, biomarker discovery at OMICs level is moving away from the idealized single cancerspecific biomarker. Seldom there is a single biomarker with both high levels of specificity and sensitivity that can meet the requirement for routine clinical practices, due to the molecular heterogeneity of tumours [19]. Although an individual biomarker maybe specific and sensitive only for a certain molecular aetiology, combinations of many markers can transcend the heterogeneity to reach higher specificity and sensitivity. Thus, the cancer-specific peptide panel may play a crucial role in the diagnosis of cancers.

There were several limitations of this study must be demonstrated. Due to the small sample size of the earlystage patients in the cohorts, we were unable to compare the differences in peptides between the early-stage patients and the healthy controls. This weakness may restrict the clinical value of the panel in early detection of CRC. Further case-control study including more early-stage patients or a prospective cohort study in design should be performed to determine the diagnostic value of the peptide panel. In addition, the peptides are fragments of proteins involved in acute phase and inflammatory response. Thus, the specificity of proposed biomarkers may be doubted. Further studies including functional analysis are essential to answer this question. Finally, because of the identification of proteases was not our primary goal of the study, we did not research the cancer-specific proteases activities. Studies that focus on cancer-specific proteases activities may shed light on CRC pathophysiology and find possible targets for CRC therapy.

In conclusion, using MALDI-TOF MS and LC$\mathrm{MS} / \mathrm{MS}$, we have characterized 5 peptides (peaks at $m / z 1895.3,2020.9,2080.7,2656.8$ and 3238.5) to be novel candidate biomarkers for CRC diagnosis. We have constructed a peptide diagnostic panel that could diagnose CRC with an accuracy of $91.8 \%$, sensitivity of 
$95.6 \%$, specificity of $87.9 \%$ and AUC value of 0.932 . As a diagnostic panel, there is potential for this method to provide an in vitro diagnosis tool for CRC. We have also identified the amino acid sequences of peptides fragments (peaks at $m / z$ 1895.3, 2020.9 and 3238.5) from C3, C4 and FGA, suggesting that increased levels of C3, C4 and FGA might associate with the pathogenesis of $\mathrm{CRC}$.

\section{MATERIALS AND METHODS}

\section{Participants}

The discovery cohort containing 100 patients with CRC and 100 healthy individuals recruited from Beijing Shijitan Hospital between January 2013 and December 2014. The independent validation cohort consisted of 91 patients with CRC and 91 healthy participants recruited from another hospital, Beijing Friendship Hospital, between March 2011 and December 2012. Each CRC patient underwent a colonoscopic biopsy and was diagnosed by two senior pathologists according to World Health Organization (WHO) diagnostic criteria [61]. Pathological samples were classified according to the TNM stage classification system [61]. All healthy controls and CRC patients were genderand age- matched.

Controls should meet the following inclusion criteria: (1) older than 18 years old, (2) capable of giving informed consent, and (3) confirmed to be healthy without any diseases detected during physical examination. Controls were excluded if they met any of the following criteria: (1) had previous history of cancer, (2) had used any drugs, and (3) were pregnant or breastfeeding.

The patients with CRC met the following inclusion criteria: (1) older than 18 years, (2) capable of giving informed consent, and (3) had colorectal cancer. Patients were excluded if they had any of the following: (1) other cancers; (2) a history of other cancers; (3) a history of radiotherapy or chemotherapy; (4) any severe diseases concerning the cardiovascular system, respiratory system, genitourinary system, digestive system or circulatory system; or (5) a systemic infection. The study was approved by the ethical committee of Capital Medical University, Beijing.

\section{Collection of serum samples}

Fasting blood samples from the participants were collected in the morning and allowed to clot at $37^{\circ} \mathrm{C}$ for 30 mins. All blood samples from the CRC patients were obtained before the colorectal surgery. Serum was then separated by centrifugation at $3000 \mathrm{rpm}$ for $15 \mathrm{mins}$ and then stored at $-80^{\circ} \mathrm{C}$ until further analysis.

\section{Peptides fractionation}

All serum samples were fractionated using MBWCX kit, according to the instructions provided by the supplier (ClinProt ${ }^{\mathrm{TM}}$, Bruker Daltonics, Billerica, MA, USA) [62]. The samples were purified and isolated in three steps: binding, washing, and elution. Firstly, $10 \mu \mathrm{l}$ beads, $10 \mu \mathrm{l}$ MB-WCX binding solution and $5 \mu \mathrm{l}$ serum were added in a $0.2 \mathrm{ml}$ polypropylene tube, mixed by pipetting up and down several times, and then incubated for $5 \mathrm{~min}$. Secondly, the tubes were placed on a magnetic bead separator for $1 \mathrm{~min}$ and the beads were grasped on the tube wall. The supernatant was removed and $100 \mu \mathrm{l}$ of magnetic bead washing solution was added, and mixed thoroughly. After three times washing, the bound peptides were eluted from the magnetic beads by $5 \mu$ of eluting solution.

\section{Peptides profiling by MALDI-TOF MS and processing of spectral data}

A portion of the eluted sample was diluted (1:10) in $\alpha$-cyano-4-hydroxycinnamic acid (CHCA) matrix solution $(0.5 \mathrm{~g} / \mathrm{L}$ CHCA in acetonitrile/water $1: 1 v / v$ containing $0.1 \%$ trifluoroacetic acid) (Sigma-Aldrich, St, Louis, MO, USA). Then $1 \mu \mathrm{l}$ of the mixture was spotted onto a MALDI-TOF MS target (Bioyong Tech, Beijing, China) and dried at room temperature before analysis. Spectral profiles were acquired using a MALDI-TOF MS (ClinTOF $^{\mathrm{TM}}$, Bioyong Tech, Beijing, China). The instrument was calibrated using a mix of commercial peptide and protein calibration standards (Sigma-Aldrich, St, Louis, MO, USA) prepared in the same matrix solution as above. Spectra were acquired automatically in a 1,000-10,000 mass-to-change ratio $(\mathrm{m} / \mathrm{z})$ range in linear mode. Each spectrum was the sum of 1,000 laser shots per spotted sample, delivered to different locations on the spot in 10 sets of 100 shots (at a laser frequency of $10 \mathrm{~Hz}$ ).

All spectra obtained from the MALDI-TOF MS were pre-processed using BioExplorer ${ }^{\mathrm{TM}} 2.0$ (Bioyong Tech, Beijing, China) [63]. In brief, the background was estimated and then subtracted from each spectrum based on local noise estimators. Peaks were detected using a signal-to-noise ratio $(\mathrm{S} / \mathrm{N})$ cut-off of 5.0, which was found to be a good compromise between overdetection and sensitivity. To align the spectra, a mass shift of no more than $0.1 \%$ was determined. Smoothing was applied by averaging the intensities within a 5-point width moving window followed by baseline subtraction using an algorithm based on finding the lowest points between dominant local intensity maxima within a particular mass window. Normalization was performed by dividing the intensity of each data point in a spectrum by the sum of all intensities in that spectrum.

\section{Peptide identification by LC-MS/MS}

The amino acid sequences of the candidate peptides were identified using a nano-liquid chromatographyelectrospray ionization-tandem mass spectrometry (nano- 
LC/ESI-MS/MS) consisting of an Aquity ${ }^{\mathrm{TM}}$ UPLC system (Waters, Milford, MA, USA) and a LTQ Orbitrap XL mass spectrometer (Thermo Fisher Scientific, Pittsburgh, PA, USA) equipped with a nano-ESI source. A sample of $5 \mu \mathrm{l}$ solution was injected on the column. The mobile phase $\mathrm{A}$, mobile phase $\mathrm{B}$, flow rate and gradient elution were operated according to the published methods [16]. The obtained samples were further analysed using the MS/MS instrument. The Mascot 2.4.1 (Matrix Science, London, UK) was used to search the database. The results were restricted to "Homo sapiens" with the peptide mass tolerance set to $\pm 20 \mathrm{ppm}$ and the fragment mass tolerance set to $\pm 0.2 \mathrm{Da}$.

\section{Statistical analysis}

Statistical analyses and displays were performed using SPSS 19.0 (IBM Corporation, New York, USA) and GraphPad Prism 5.0 (GraphPad, San Diego, USA). Normality of variables was tested by Shapiro-Wilk test. Student's $t$ test was used to compare normally distributed continuous data, and the Mann-Whitney U-test was used for non-normally distributed continuous data. The chi-square test was used for the analysis of categorical data. Differential peptide peaks were used to establish a diagnostic panel by multivariate binary logistic regression. Receiver operating characteristic (ROC) curves and the area under the curve (AUC) were used to assess the diagnostic performance of the model. $P<0.05$ was considered statistically significant (two-tailed).

\section{Abbreviations}

CRC, colorectal cancer; MB-WCX, weak cation exchange magnetic beads; MALDI-TOF MS, matrixassisted laser desorption/ionization time-of-flight mass spectrometry; LC-MS/MS, liquid chromatography-tandem mass spectrometry; $\mathrm{C} 3$, complement component 3; $\mathrm{C} 4$, complement component 4; FGA, fibrinogen $\alpha$ chain; FOBT, fecal occult blood test; CEA, carcinoembryonic antigen

\section{Author contributions}

WW, YW and CL participated in the design of the study. CL, SZ, HF, QG, and SG performed patients' enrollments, the measurements, and collected the samples. HW, HQ and QM, performed the peptide analysis. HW and YW performed the statistical analysis and drafted the manuscript. WW, YW and CL revised the manuscript.

\section{ACKNOWLEDGMENTS}

We thank engineers from Bioyong Technology for MS data analysis. We are grateful to all the participants whose blood made this study possible.

\section{CONFLICTS OF INTEREST}

The authors declare that there are no conflicts of interest.

\section{FUNDING}

The study was supported by grants from National Natural Science Foundation of China (NSFC 81372586, 81370083, 81273170), Beijing Nova Program (Z141107001814058), the Joint Project of the Australian National Health and Medical Research Council and the National Natural Science Foundation of China (NHMRC APP1112767-NSFC 81561128020), and Australian National Health and Medical Research Council Grant (NHMRC-APP1046711).

\section{REFERENCES}

1. Stewart BW, Wild CP. World cancer report 2014: World Health Organization. 2014.

2. Torre LA, Bray F, Siegel RL, Ferlay J, Lortet-Tieulent J, Jemal A. Global cancer statistics, 2012. CA Cancer J Clin. 2015; 65:87-108.

3. DeSantis CE, Lin CC, Mariotto AB, Siegel RL, Stein KD, Kramer JL, Alteri R, Robbins AS, Jemal A. Cancer treatment and survivorship statistics, 2014. CA Cancer J Clin. 2014; 64:252-271.

4. Smith RA, Manassaram-Baptiste D, Brooks D, Doroshenk M, Fedewa S, Saslow D, Brawley OW, Wender R. Cancer screening in the United States, 2015: a review of current American cancer society guidelines and current issues in cancer screening. CA Cancer J Clin. 2015; 65:30-54.

5. Siegel R, Desantis C, Jemal A. Colorectal cancer statistics, 2014. CA Cancer J Clin. 2014; 64:104-117.

6. Harrison NM, Hjelkrem MC. Bowel cleansing before colonoscopy: balancing efficacy, safety, cost and patient tolerance. World J Gastrointest Endosc. 2016; 8:4-12.

7. Khalid-de Bakker CA, Jonkers DM, Hameeteman W, de Ridder RJ, Masclee AA, Stockbrügger RW. Opportunistic screening of hospital staff using primary colonoscopy: participation, discomfort and willingness to repeat the procedure. Digestion. 2011; 84:281-288.

8. Singh H, Penfold RB, De Coster C, Au W, Bernstein CN, Moffatt M. Predictors of serious complications associated with lower gastrointestinal endoscopy in a major city-wide health region. Can J Gastroenterol. 2010; 24:425-430.

9. Leggett BA, Hewett DG. Colorectal cancer screening. Intern Med J. 2015; 45:6-15.

10. Littlejohn C, Hilton S, Macfarlane GJ, Phull P. Systematic review and meta-analysis of the evidence for flexible sigmoidoscopy as a screening method for the prevention of colorectal cancer. Br J Surg. 2012; 99:1488-1500. 
11. Tarraga LP, Albero JS, Rodriguez-Montes JA. Primary and secondary prevention of colorectal cancer. Clin Med Insights Gastroenterol. 2014; 7:33-46.

12. Duffy MJ. Carcinoembryonic antigen as a marker for colorectal cancer: is it clinically useful? Clin Chem. 2001; 47:624-630.

13. Duffy MJ, van Dalen A, Haglund C, Hansson L, Klapdor R, Lamerz R, Nilsson O, Sturgeon C, Topolcan O. Clinical utility of biochemical markers in colorectal cancer: European Group on Tumour Markers (EGTM) guidelines. Eur J Cancer. 2003; 39:718-727.

14. Mahboob S, Mohamedali A, Ahn SB, Schulz-Knappe P, Nice E, Baker MS. Is isolation of comprehensive human plasma peptidomes an achievable quest? J Proteomics. 2015; 127:300-309.

15. Tirumalai RS, Chan KC, Prieto DA, Issaq HJ, Conrads TP, Veenstra TD. Characterization of the low molecular weight human serum proteome. Mol Cell Proteomics. 2003; 2:1096-1103.

16. Lu J, Huang Y, Wang Y, Li Y, Zhang Y, Wu J, Zhao F, Meng S, Yu X, Ma Q, Song M, Chang N, Bittles AH, Wang W. Profiling plasma peptides for the identification of potential ageing biomarkers in Chinese Han adults. PLoS One. 2012; 7:e39726.

17. Meng Q, Ge S, Yan W, Li R, Dou J, Wang H, Wang B, Ma Q, Zhou Y, Song M, Yu X, Wang H, Yang X, et al. Screening for potential serum-based proteomic biomarkers for human type 2 diabetes mellitus using MALDI-TOF MS. Proteomics Clin Appl. 2016; 11:3-4.

18. Lopez MF, Mikulskis A, Kuzdzal S, Bennett DA, Kelly J, Golenko E, DiCesare J, Denoyer E, Patton WF, Ediger R, Sapp L, Ziegert T, Lynch C, et al. High-resolution serum proteomic profiling of Alzheimer disease samples reveals diseasespecific, carrier-protein-bound mass signatures. Clin Chem. 2005; 51:1946-1954.

19. Petricoin EF, Belluco C, Araujo RP, Liotta LA. The blood peptidome: a higher dimension of information content for cancer biomarker discovery. Nat Rev Cancer. 2006; 6:961-967.

20. Fan NJ, Gao CF, Wang XL, Zhao G, Liu QY, Zhang YY, Cheng BG. Serum peptidome patterns of colorectal cancer based on magnetic bead separation and MALDI-TOF mass spectrometry analysis. J Biomed Biotechnol. 2012; 2012:985020.

21. Deng BG, Yao JH, Liu QY, Feng XJ, Liu D, Zhao L, Tu B, Yang F. Comparative serum proteomic analysis of serum diagnosis proteins of colorectal cancer based on magnetic bead separation and maldi-tof mass spectrometry. Asian Pac J Cancer Prev. 2013; 14:6069-6075.

22. de Noo ME, Mertens BJ, Ozalp A, Bladergroen MR, van der Werff MP, van de Velde CJ, Deelder AM, Tollenaar RA. Detection of colorectal cancer using MALDI-TOF serum protein profiling. Eur J Cancer. 2006; 42:1068-1076.
23. Engwegen JY, Helgason HH, Cats A, Harris N, Bonfrer JM, Schellens JH, Beijnen JH. Identification of serum proteins discriminating colorectal cancer patients and healthy controls using surface-enhanced laser desorption ionisationtime of flight mass spectrometry. World J Gastroenterol. 2006 ; $12: 1536-1544$.

24. Liu XP, Shen J, Li ZF, Yan L, Gu J. A serum proteomic pattern for the detection of colorectal adenocarcinoma using surface enhanced laser desorption and ionization mass spectrometry. Cancer Invest. 2006; 24:747-753.

25. Pietrowska M, Polanska J, Suwinski R, Widel M, Rutkowski T, Marczyk M, Dominczyk I, Ponge L, Marczak L, Polanski A, Widlak P. Comparison of peptide cancer signatures identified by mass spectrometry in serum of patients with head and neck, lung and colorectal cancers: association with tumor progression. Int J Oncol. 2012; 40:148-156.

26. Zhai XH, Yu JK, Yang FQ, Zheng S. Identification of a new protein biomarker for colorectal cancer diagnosis. Mol Med Rep. 2012; 6:444-448.

27. Ward DG, Suggett N, Cheng Y, Wei W, Johnson H, Billingham LJ, Ismail T, Wakelam MJ, Johnson PJ, Martin A. Identification of serum biomarkers for colon cancer by proteomic analysis. Br J Cancer. 2006; 94:1898-1905.

28. Yu JK, Chen YD, Zheng S. An integrated approach to the detection of colorectal cancer utilizing proteomics and bioinformatics. World J Gastroenterol. 2004; 10:3127-3131.

29. Chen YD, Zheng S, Yu JK, Hu X. Artificial neural networks analysis of surface-enhanced laser desorption/ionization mass spectra of serum protein pattern distinguishes colorectal cancer from healthy population. Clin Cancer Res. 2004; 10:8380-8385.

30. Habermann JK, Roblick UJ, Luke BT, Prieto DA, Finlay WJ, Podust VN, Roman JM, Oevermann E, Schiedeck T, Homann N, Duchrow M, Conrads TP, Veenstra $\mathrm{TD}$, et al. Increased serum levels of complement C3a anaphylatoxin indicate the presence of colorectal tumors. Gastroenterology. 2006; 131:1020-1029, 1284.

31. Qiu F, Liu HY, Zhang XJ, Tian YP. Optimization of magnetic beads for maldi-TOF MS analysis. Front Biosci. 2009; 14:3712-3723.

32. Hortin GL. The MALDI-TOF mass spectrometric view of the plasma proteome and peptidome. Clin Chem. 2006; 52:1223-1237.

33. Aebersold R, Mann M. Mass spectrometry-based proteomics. Nature. 2003; 422:198-207.

34. Cottrell JS. Protein identification using MS/MS data. J Proteomics. 2011; 74:1842-1851.

35. Pietrowska M, Widlak P. MALDI-MS-based profiling of serum proteome: detection of changes related to progression of cancer and response to anticancer treatment. Int J Proteomics. 2012; 2012:926427. 
36. Merle NS, Church SE, Fremeaux-Bacchi V, Roumenina LT. Complement system part I - molecular mechanisms of activation and regulation. Front Immunol. 2015; 6:262.

37. Sarma JV, Ward PA. The complement system. Cell Tissue Res. 2011; 343:227-235.

38. Pio R, Corrales L, Lambris JD. The role of complement in tumor growth. Adv Exp Med Biol. 2014; 772:229-262.

39. Botto M, Kirschfink M, Macor P, Pickering MC, Wurzner $\mathrm{R}$, Tedesco F. Complement in human diseases: lessons from complement deficiencies. Mol Immunol. 2009; 46:2774-2783.

40. Pettigrew HD, Teuber SS, Gershwin ME. Clinical significance of complement deficiencies. Ann N Y Acad Sci. 2009; 1173:108-123.

41. Bijl M, Reefman E, Horst G, Limburg PC, Kallenberg CG. Reduced uptake of apoptotic cells by macrophages in systemic lupus erythematosus: correlates with decreased serum levels of complement. Ann Rheum Dis. 2006; 65:57-63.

42. Merle NS, Noe R, Halbwachs-Mecarelli L, FremeauxBacchi V, Roumenina LT. Complement system part II: role in immunity. Front Immunol. 2015; 6:257.

43. Ricklin D, Hajishengallis G, Yang K, Lambris JD. Complement: a key system for immune surveillance and homeostasis. Nat Immunol. 2010; 11:785-797.

44. Mamidi S, Hone S, Kirschfink M. The complement system in cancer: Ambivalence between tumour destruction and promotion. Immunobiology. 2015; 222:45-54.

45. Bjorge L, Hakulinen J, Vintermyr OK, Jarva H, Jensen TS, Iversen $\mathrm{OE}$, Meri S. Ascitic complement system in ovarian cancer. Br J Cancer. 2005; 92:895-905.

46. Ytting H, Jensenius JC, Christensen IJ, Thiel S, Nielsen HJ. Increased activity of the mannan-binding lectin complement activation pathway in patients with colorectal cancer. Scand J Gastroenterol. 2004; 39:674-679.

47. Watson NF, Durrant LG, Madjd Z, Ellis IO, Scholefield $\mathrm{JH}$, Spendlove I. Expression of the membrane complement regulatory protein CD59 (protectin) is associated with reduced survival in colorectal cancer patients. Cancer Immunol Immunother. 2006; 55:973-980.

48. Kamath S, Lip GY. Fibrinogen: biochemistry, epidemiology and determinants. QJM. 2003; 96:711-729.

49. Son HJ, Park JW, Chang HJ, Kim DY, Kim BC, Kim SY, Park SC, Choi HS, Oh JH. Preoperative plasma hyperfibrinogenemia is predictive of poor prognosis in patients with nonmetastatic colon cancer. Ann Surg Oncol. 2013; 20:2908-2913.

50. Palumbo JS, Kombrinck KW, Drew AF, Grimes TS, Kiser $\mathrm{JH}$, Degen JL, Bugge TH. Fibrinogen is an important determinant of the metastatic potential of circulating tumor cells. Blood. 2000; 96:3302-3309.

51. Palumbo JS, Talmage KE, Massari JV, La Jeunesse CM, Flick MJ, Kombrinck KW, Jirouskova M, Degen JL.
Platelets and fibrin(ogen) increase metastatic potential by impeding natural killer cell-mediated elimination of tumor cells. Blood. 2005; 105:178-185.

52. Yamashita H, Kitayama J, Taguri M, Nagawa H. Effect of preoperative hyperfibrinogenemia on recurrence of colorectal cancer without a systemic inflammatory response. World J Surg. 2009; 33:1298-1305.

53. Tang L, Liu K, Wang J, Wang C, Zhao P, Liu J. High preoperative plasma fibrinogen levels are associated with distant metastases and impaired prognosis after curative resection in patients with colorectal cancer. J Surg Oncol. 2010; 102:428-432.

54. Kawai K, Kitayama J, Tsuno NH, Sunami E, Nagawa H. Hyperfibrinogenemia after preoperative chemoradiotherapy predicts poor response and poor prognosis in rectal cancer. Int J Colorectal Dis. 2011; 26:45-51.

55. Jones JM, McGonigle NC, McAnespie M, Cran GW, Graham AN. Plasma fibrinogen and serum C-reactive protein are associated with non-small cell lung cancer. Lung Cancer. 2006; 53:97-101.

56. Guo Q, Zhang B, Dong X, Xie Q, Guo E, Huang H, Wu Y. Elevated levels of plasma fibrinogen in patients with pancreatic cancer: possible role of a distant metastasis predictor. Pancreas. 2009; 38:e75-e79.

57. Polterauer S, Grimm C, Seebacher V, Concin N, Marth C, Tomovski C, Husslein H, Leipold H, Hefler-Frischmuth K, Tempfer C, Reinthaller A, Hefler L. Plasma fibrinogen levels and prognosis in patients with ovarian cancer: a multicenter study. Oncologist. 2009; 14:979-985.

58. Yamashita H, Kitayama J, Kanno N, Yatomi Y, Nagawa H. Hyperfibrinogenemia is associated with lymphatic as well as hematogenous metastasis and worse clinical outcome in T2 gastric cancer. BMC Cancer. 2006; 6:147.

59. Carl-McGrath S, Lendeckel U, Ebert M, Wolter AB, Roessner A, Rocken C. The ectopeptidases CD10, CD13, $\mathrm{CD} 26$, and CD143 are upregulated in gastric cancer. Int J Oncol. 2004; 25:1223-1232.

60. Selvakumar P, Lakshmikuttyamma A, Kanthan R, Kanthan SC, Dimmock JR, Sharma RK. High expression of methionine aminopeptidase 2 in human colorectal adenocarcinomas. Clin Cancer Res. 2004; 10:2771-2775.

61. Hamilton SR. World Health Organization classification of tumors: tumours of the colon and rectum. Pathology and genetics of tumors of digestive system. 2003.

62. Ketterlinus R, Hsieh SY, Teng SH, Lee H, Pusch W. Fishing for biomarkers: analyzing mass spectrometry data with the new ClinProTools software. Biotechniques. 2005; Suppl:37-40.

63. Jia K, Li W, Wang F, Qu H, Qiao Y, Zhou L, Sun Y, Ma $\mathrm{Q}$, Zhao X. Novel circulating peptide biomarkers for esophageal squamous cell carcinoma revealed by a magnetic bead-based MALDI-TOFMS assay. Oncotarget. 2016; 7:23569-23580. https://doi.org/10.18632/oncotarget.8123. 